\title{
ANALISIS DAYA DUKUNG EKOLOGI UNTUK PENGEMBANGAN BUDIDAYA RUMPUT LAUT DI BAGIAN UTARA TELUK BONE
}

\author{
Ecological Carrying Capacity Analysis For Development Of Seaweed \\ Cultivation In The Nothern Gulf Of Bone
}

\author{
Taslim Arifin ${ }^{1}$ dan Waluyo ${ }^{2}$
}

Diterima:13 April 2017 Disetujui: 15 Februari 2018

\begin{abstract}
Abstrak : Budidaya rumput laut jenis Eucheuma cottonii perlu dilakukan dengan memperhatikan daya dukung perairan (waters carrying capacity) agar diketahui kapasitas optimum budidaya rumput laut pada suatu perairan. Tujuan penelitian ini adalah untuk mengetahui ketersediaan ruang ekologi perairan dan menghitung daya dukung untuk pengembangan budidaya rumput laut. Pendekatan yang dapat digunakan untuk menentukan daya dukung adalah dengan analisis ecological footprint (EF). Pemetaan dan analisis kesesuaian lahan dilakukan dengan bantuan perangkat lunak Sistem Informasi Geografis. Hasil penelitian menunjukkan bahwa ecological footprint produksi $\left(\mathrm{EF}_{\mathrm{P}}\right) \mathrm{di}$ perairan Kabupaten Luwu adalah 67,88 ton/kapita/tahun atau setara dengan 235.823,93 ton/tahun. Berdasarkan analisis ketersediaan perairan untuk rumput laut adalah 59.781,79 hektar mampu memproduksi rumput laut (biocapacity) sebanyak 1.437.779,60 ton/tahun dan daya dukung (carrying capacity) jumlah pembudidaya yang memungkinkan untuk memanfaatkan lahan sebanyak 21.432 kapita. Ecological footprint produksi $(\mathrm{EFP})$ di perairan Kota Palopo adalah 3,08 ton/kapita/tahun atau setara dengan 4.589,99 ton/tahun. Berdasarkan analisis ketersediaan perairan adalah 1.771,41 hektar mampu untuk memproduksi rumput laut (biocapacity) sebanyak 18.287,46 ton/tahun dan daya dukung (carrying capacity) jumlah pembudidaya sebanyak 635 kapita. Berdasarkan hasil perbandingan antara biocapacity dan ecological footprint, maka status ekologi di perairan Kabupaten Luwu dan Kota Palopo masih dalam kondisi pemanfaatan yang berkelanjutan.
\end{abstract}

\section{Kata kunci : budidaya rumput laut, ecological footprint, biocapacity, daya dukung perairan}

\begin{abstract}
Waters carrying capacity in seaweed (Eucheuma cottonii) cultures should be a concern for optimum seaweed culture. The purpose of this study was to determine the availability of water ecological space and calculate the carrying capacity for the development of seaweed cultivation. Carrying capacity can determine by ecological footprint (EF) Map and land use analyzed with GIS (Geographic Information Systems).The results showed that theecological footprint production (EFP)in Luwu waters is 67.88 ton/capita/year, or equivalent to $235,823.93$ tons/year.Based on the analysis of the availability of water for seaweed is 59,781.79 hectares, it can produce seaweed (biocapacity) for 1,437,779.60 tons/year and the number of farmers that allows for use the waters is 21,432 capita. The ecological footprint production (EFp) in Palopo waters is 3.08 ton/capita/year, or equivalent to 4,589.99 tons/year. Water availability analysis is $1,771.41$ hectares are able to produce seaweed (biocapacity) for $18,287.46$ ton/year and the number of farmers that allows for use the waters is 635 farmers capita. The results
\end{abstract}

\footnotetext{
${ }^{1}$ Pusat Riset Kelautan - Badan Riset \& Sumberdaya Manusia Kelautan \& Perikanan, KKP

${ }^{2}$ Politeknik Kelautan dan Perikanan, Karawang - BRSDM-KP KKP
}

Korespondensi: a_taslimar@yahoo.com 
comparison between biocapacity and ecological footprint, ecological status for Luwu and Palopo waters are still in sustainable use.

Keywords : seaweed cultivation, ecological footprint, biocapacity, waters carrying capacity

\section{PENDAHULUAN}

Kontribusi Provinsi Sulawesi Selatan terhadap produksi rumput laut nasional sebesar 25 \%. Produksi Rumput Laut Sulawesi Selatan Tahun 2015 sebesar 3,29 juta ton basah naik $14 \%$ dari tahun sebelumnnya terdiri dari Eucheuma cottonii2,17 juta ton naik $12 \%$; gracilaria 0,88 juta ton naik 6\% dan spinosum 0,24 juta ton naik $95 \%$ (DKP Provinsi Sulawesi Selatan, 2016). Salah satu pusat produksi rumput laut Sulawesi Selatan adalah wilayah Teluk Bone.Perairan Teluk Bone secara administratif terletak di Propinsi Sulawesi Selatan di sebelah barat dan utara, dan Propinsi Sulawesi Tenggara di sebelah timur.

Berdasarkan data Dinas Kelautan dan Perikanan (DKP) Kabupaten Luwu tahun 2015 menyatakan bahwa rata-rata produktivitas rumput laut dari tahun 2008-2014 mencapai sebesar 24,05 ton/hektar/tahun. Adapun produktivitas rumput laut di Kota Palopo dari tahun 2008-2014 mencapai 10,32 ton/hektar/tahun (DKP Kota Palopo, 2015). Produktivitas perairan di Kabupaten Luwu sangat tinggi disebabkan diantaranya adalah lahan perairan budidaya yang luas dan jumlah pembudidaya rumput laut yang lebih banyak dibandingkan dengan di Kota Palopo.Rata-rata pembudidaya di Kabupaten Luwu pada tahun 2008-2014 mencapai 3.472 kapita, sedangkan di Kota Palopo hanya mencapai 1.503 kapita.

Dari data tersebut di atas menunjukkan bahwa perairan Kabupaten Luwu dan Kota Palopo memiliki potensi yang cukup besar untuk budidaya rumput laut.Agar dapat mengoptimalkan potensi tersebut diperlukan evaluasi daya dukung perairan pesisir untuk keberkelanjutaneksploitasi produktivitas biologis (Ken Furuya, 2004), dan pemahaman tentang masalah lingkungan yang terkait dengan kegiatan budidaya (Todaet al. 2007) serta upaya pengelolaan secara terpadu sehingga dapat mempertahankan dan meningkatkan baik dari faktor produksi maupun kualitas rumput laut di daerah tersebut. Salah satu cara yang dapat digunakan adalah dengan mengetahui seberapa besar daya dukung suatu perairan yang dapat mendukung usaha budidaya rumput laut. Keberlanjutan produksi budidaya rumput lautberdasarkan perubahan musim dan lingkungan ekologi diharapkan dapat menjadi acuan dalam pengelolan dan pemanfaatan perairan pesisir secara optimal.

Daya dukung perairan diperlukan untuk menentukan kapasitas optimum budidaya rumput laut.Daya dukung pada penelitian ini mencakup berapa luas lahan perairan tersebut yang dapat dimanfaatkan secara optimal, berapa besar perairan tersebut dapat memproduksi rumput laut, serta berapa banyak sumberdaya manusia yang memungkinkan dapat memanfaatkan lahan yang tersedia. Dengan mengetahui tingkat pemanfaatan dan daya dukung suatu perairan, maka akan dapat dijadikan landasan dalam pengelolaan suatu perairan sehingga tingkat pemanfaatan tidak melebihi daya dukung yang ada. Tujuan penelitian ini adalah untuk mengetahui ketersediaan ruang ekologi perairan dan menghitung daya dukung untuk pengembangan budidaya rumput laut.

\section{METODE}

\section{Waktu dan Lokasi Penelitian}

Penelitian dilaksanakan dengan dua tahap, yaitu tahap 1 dilaksanakan pada bulan Mei 2015 (musim peralihan 1) dan tahap 2 pada bulan September 2015 (musim peralihan 2) di perairan pesisir Kabupaten Luwu dan Kota Palopo, Teluk Bone, Sulawesi Selatan. Pengambilan data primer dilakukan pada 18 titik stasiun.Peta lokasi penelitian ditampilkan pada Gambar 1. 


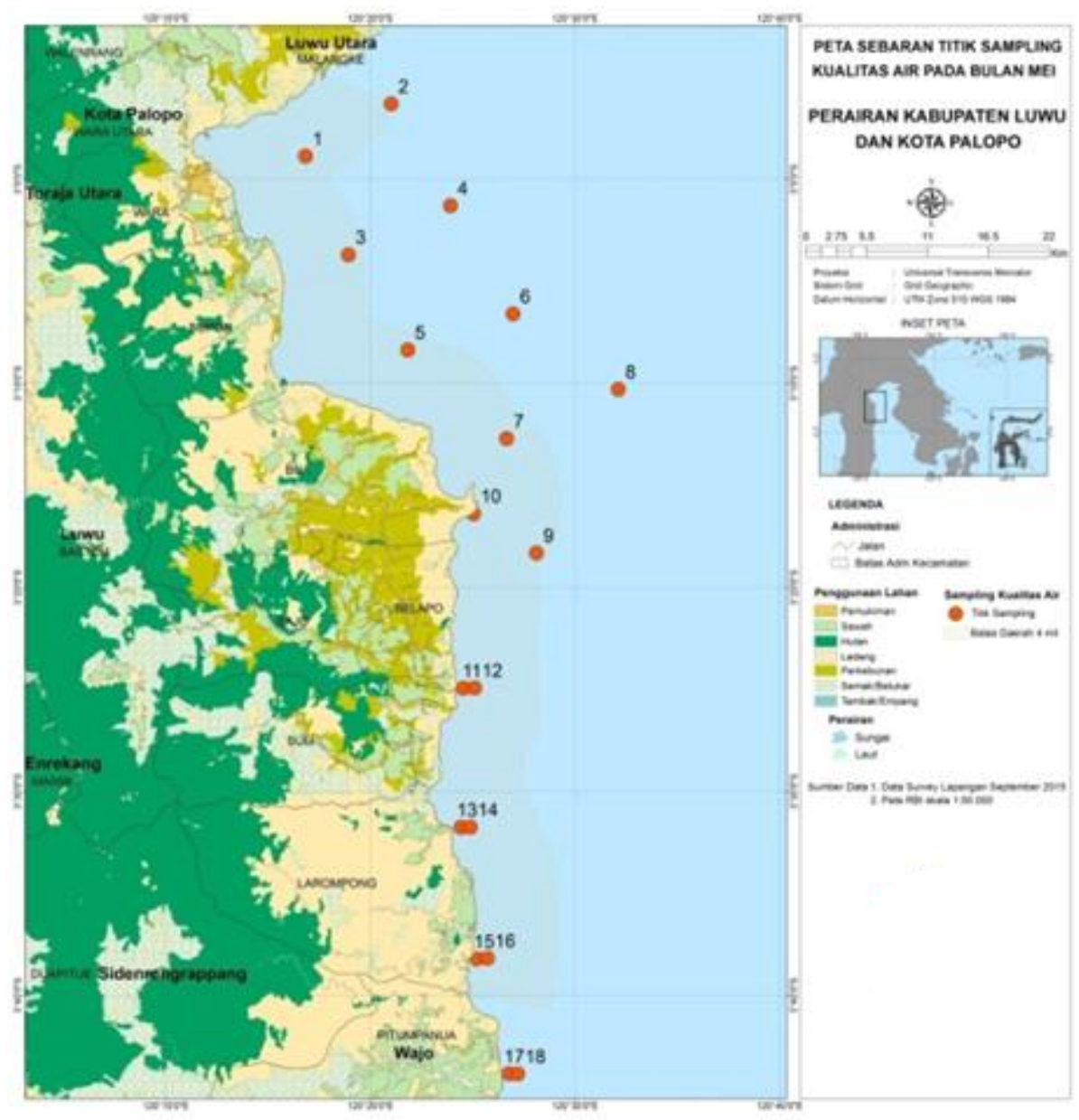

Gambar 1.Peta Iokasi penelitian.

Data

Data primer yang diambil secara insitu meliputi suhu air laut, salinitas, $\mathrm{pH}$, oksigen terlarut dan arus. Data suhu dan oksigen terlarut diukur menggunakan DO meter, salinitas menggunakan refraktometer, $\mathrm{pH}$ menggunakan $\mathrm{pH}$ meter dan arus menggunakan current meter dan dari data HyCom + NCODA bulan Mei dan September 2015.ParameterTotal Suspended Solid (TSS), Chemical Oxygen Demand (COD), nitrat, fosfat, amoniak, clorofil-a, serta logam berat $\mathrm{Pb}$, $\mathrm{Cd}$ dan $\mathrm{Hg}$, diambil dengan menggunakan botol niskin pada kedalaman 2 meter.Data-datatersebut dianalisis di laboratorium Balai Penelitian dan Pengembangan Budidaya Air Payau - Maros.Data sekunder pasang surut berasal dari BIG (2015), data kemiringan dan panjang garis pantai berasal dari DKP Kabupaten Luwu dan Kota Palopo.

\section{Analisis Data}

Analisis daya dukung perairan meliputi tiga komponen utama, yaitu : 1) berapa besar tingkat pemanfaatan perairan (dalam hal ini adalah Ecological Footprint Produksi/ $\mathrm{EF}_{\mathrm{P}}$ ), 2) berapa besar ketersediaan perairan (Biocapacity/BC) yang mampu untuk mendukung kegiatan tersebut, serta, 3) berapa banyak jumlah sumberdaya manusia yang memungkinkan untuk memanfaatkan ketersediaan ruang perairan yang ada. Dengan membandingkan antara Biocapacity terhadap Ecological Footprint maka akan menghasilkan berapa besar daya dukung perairan. 


\section{Analisis Pemanfaatan Ruang Perairan}

Analisis pemanfaatan ruang perairan pada penelitian ini adalah analisis Ecological Footprint Produksi $\left(\mathrm{EF}_{\mathrm{P}}\right)$ yang didasarkan pada tingkat produksi rumput laut terhadap jumlah pembudidaya, dengan persamaan sebagai berikut (Ewing et al., 2010):

$$
E F_{P}=\frac{P}{Y_{N}}
$$

Keterangan

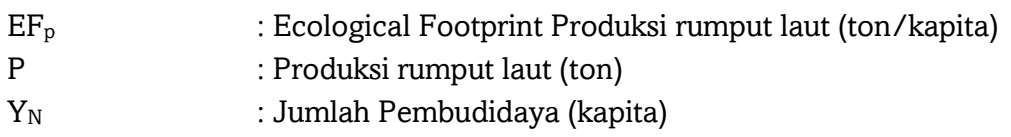

\section{Analisis Ketersediaan Ruang Perairan}

Analisis ketersediaan ruang perairan (biocapacity) didasarkan pada kesesuaian perairan untuk mendukung budidaya rumput laut.Konsep ini berdasarkan pada parameter fisika, kimia dan biologi perairan yang secara ekologis merupakan prasyarat kelayakan dalam budidaya rumput laut.Untuk itu digunakan teknik Sistem Informasi Geografis (SIG) untuk mengetahui luas perairan yang sesuai untuk budidaya rumput laut. Berdasarkan kategori kelas kesesuaian budidaya rumput laut, maka digunakan untuk menghitung biocapacity (kemampuan luas perairan yang tersedia) dengan rumus sebagai berikut (Bala and Hossain, 2009):

$$
\text { Biocapacity =Luas kesesuaian lahan } x \text { faktor yield }
$$

Keterangan

Biocapacity

Luas

: Kemampuan perairan yang tersedia untuk memproduksi rumput laut (ton)

Faktor yield

: Luas lahan berdasarkan kesesuaian (hektar)

: Produktivitas rumput laut lokal (ton/hektar)

\section{Daya Dukung Berdasarkan Analisis Ecological Footprint (EF).}

Daya dukung perairan merupakan kemampuan sebuah sistem untuk mendukung kegiatan pada tingkat tertentu (UNEP 1996), dalam hal ini adalah kegiatan budidaya rumput laut jenis Eucheuma cottonii. Dengan kata lain, daya dukung terkait dengan sistem wilayah pesisir yang memiliki batas-batas tertentu atau memiliki ambang batas terhadap suatu kegiatan (MacLeod dan Cooper 2005).

Untuk mengetahui daya dukung suatu perairan berdasarkan analisis Ecological Footprint $(\mathrm{EF})$, terdapat 3 (tiga) komponen utama yang harus diketahui, yaitu : 1) seberapa besar tingkat pemanfaatan ruang perairan (dalam hal ini adalah Ecological Footprint Produksi/ $\mathrm{EF}_{\mathrm{P}}$ ), 2) seberapa besar ketersediaan ruang perairan yang mampu untuk mendukung kegiatan tersebut (Biocapacity/BC), serta, 3) berapa banyak jumlah sumberdaya manusia yang memungkinkan untuk memanfaatkan ketersediaan ruang perairan yang ada. Dengan membandingan antara Biocapacity terhadap Ecological Footprint maka akan menghasilkan seberapa besar tingkat daya dukung perairan. Persamaan untuk menghitung daya dukung adalah sebagai berikut (Yonvitner $d k k$. 2007) :

$$
C C=\frac{B C}{E F_{P}}
$$

Keterangan :

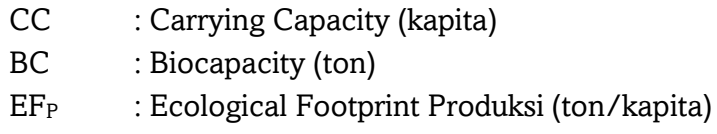




\section{HASIL DAN PEMBAHASAN}

\section{Kesesuaian Ruang Perairan}

Berdasarkan hasil analisis gabungan kesesuaian dari musim peralihan 1 dan peralihan 2, maka dihasilkan peta kesesuaian yang mencerminkan representative kesesuaian dalam 1 tahun. Berdasarkan hasil analisis menunjukkan bahwa secara umum perairan di Kota Palopo dan sebagian besar perairan Luwu bagian utara tidak sesuai untuk budidaya rumput laut. Pada perairan Kabupaten Luwu bagian selatan secara umum sesuai untuk budidaya rumput laut, akan tetapi khusus di Kecamatan Ponrang Selatan sangat sesuai untuk budidaya rumput laut. Luas perairan di Kabupaten Luwu dengan kategori sangat sesuai (S1) adalah 13.618,85 hektar, kategori sesuai (S2) 46.882,26 hektar dan kategori tidak sesuai (N) adalah 9.089,49 hektar. Apabila dengan asumsi kategori sangat sesuai (S1) dan sesuai (S2) digabungkan menjadi perairan yang layak dan sesuai untuk rumput laut, maka total luas yang sesuai adalah 60.501,11 hektar. Selain itu, berdasarkan lokasi rencana DPL di Kabupaten Luwu dengan luas 280,48 hektar, dimana DPL tersebut masuk di dalam wilayah dengan kategori sesuai (S2), maka luas kategori sangat sesuai tetap yaitu 13.618,85 hektar, kategori sesuai menjadi 46.162,94 hektar, sehingga total luasan yang layak dan sesuai setelah dikurangi luasan DPL menjadi 59.781,79 hektar. Luas perairan di Kota Palopo dengan kategori sangat sesuai (S1) adalah 0 hektar, kategori sesuai (S2) adalah 1.771,41 hektar dan tidak sesuai (N) 6.941,33 hektar. Apabila dengan asumsi kategori sangat sesuai (S1) dan sesuai (S2) digabungkan menjadi perairan yang layak dan sesuai untuk rumput laut, maka total luas yang sesuai adalah $1.771,41$ hektar.

\section{Pemanfaatan Ruang Perairan}

Produksi rumput laut Eucheuma cottonii di Kabupaten Luwu dan Kota Palopo mulai Tahun 2008-2014 cenderung mengalami peningkatan, akan tetapi jumlah nelayan pembudidaya di kedua daerah tersebut menunjukkan trend yang tidak sama. Jumlah pembudidaya Kabupaten Luwu setiap tahun mengalami peningkatan, akan tetapi di Kota Palopo cenderung mengalami penurunan. Berdasarkan data produksi dan jumlah pembudidaya, maka akan dapat dihitung $\mathrm{EF}_{\mathrm{P}}$ masing-masing daerah tersebut.

Nilai $\mathrm{EF}_{\mathrm{P}}$ rumput laut di Kabupaten Luwu menunjukkan bahwa perairan dengan rata-rata luas pemanfaatan eksisting 9.709,24 hektar dan dimanfaatkan oleh pembudidaya rumput laut sebanyak 3.472 kapita, maka perairan tersebut mampu menghasilkan produksi rumput laut $\left(\mathrm{EF}_{\mathrm{P}}\right)$ sebanyak 67,8883 ton/kapita/tahun. Demikian juga dengan $\mathrm{EF}_{\mathrm{P}}$ di Kota Palopo dengan luas lahan rata-rata sebesar 438,61 hektar dan dimanfaatkan oleh pembudidaya rumput laut sebanyak 1.503 kapita, perairan tersebut menghasilkan rumput laut $\left(\mathrm{EF}_{\mathrm{P}}\right)$ sebanyak 3,0876 ton/kapita/tahun. Nilai $\mathrm{EF}_{\mathrm{P}}$ di Kabupaten Luwu lebih tinggi dibandingkan dengan di Kota Palopo, hal ini disebabkan tingkat produksi yang tinggi serta lahan budidaya yang lebih luas.Dengan lahan yang lebih luas mempunyai peluang dan potensi menghasilkan produksi rumput laut yang lebih banyak.Hasil analisis $\mathrm{EF}_{\mathrm{P}}$ di Kabupaten Luwu dan Kota Palopo disajikan pada Tabel 1 dan Gambar 2.

Tabel 1. Ecological footprint produksi rumput laut di Kabupaten Luwu dan Kota Palopo

\begin{tabular}{|c|c|c|c|c|c|c|c|}
\hline \multirow[t]{2}{*}{ No } & \multirow[t]{2}{*}{ Tahun } & \multicolumn{2}{|c|}{ Pembudidaya (Kapita) } & \multicolumn{2}{|c|}{ Produksi (Ton/Tahun) } & \multicolumn{2}{|c|}{ EFP (Ton/Kapita/Tahun) } \\
\hline & & Kab. Luwu & Kota Palopo & Kab. Luwu & Kota Palopo & Kab. Luwu & Kota Palopo \\
\hline 1 & 2008 & 3.456 & 1.543 & $174.875,44$ & $2.195,51$ & 50,6005 & 1,4229 \\
\hline 2 & 2009 & 3.465 & 1.569 & $178.361,34$ & $2.219,83$ & 51,4751 & 1,4148 \\
\hline 3 & 2010 & 3.473 & 1.578 & $183.202,80$ & $2.227,04$ & 52,7506 & 1,4113 \\
\hline 4 & 2011 & 3.476 & 1.464 & $229.017,00$ & $3.416,25$ & 65,8852 & 2,3335 \\
\hline 5 & 2012 & 3.476 & 1.479 & $256.257,85$ & $6.416,00$ & 73,7221 & 4,3381 \\
\hline 6 & 2013 & 3.479 & 1.479 & $272.667,60$ & $12.543,00$ & 78,3753 & 8,4807 \\
\hline 7 & 2014 & 3.480 & 1.407 & $356.385,50$ & $3.112,31$ & 102,4096 & 2,2120 \\
\hline \multicolumn{2}{|c|}{ Rata-rata } & 3.472 & 1.503 & $235.823,93$ & $4.589,99$ & 67,8883 & 3,0876 \\
\hline
\end{tabular}




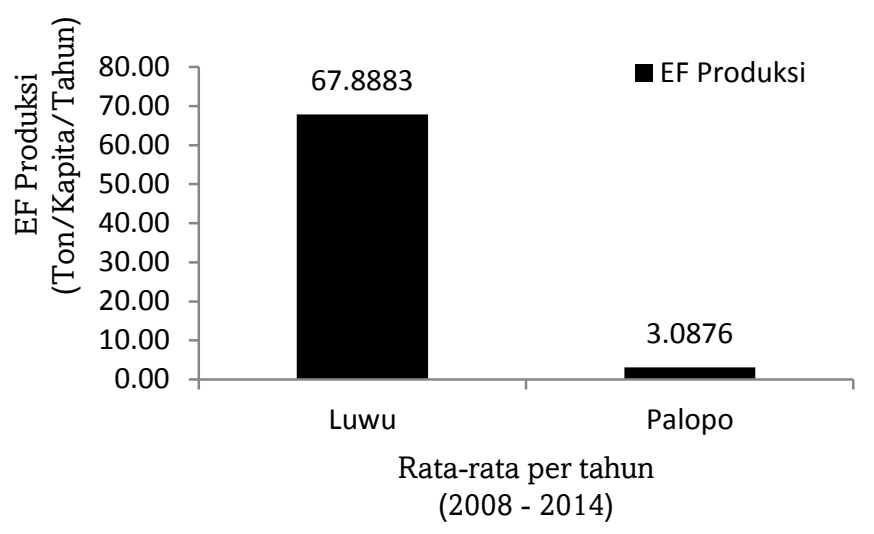

Gambar 2. Ecological footprint produksi (EFp) rumput laut Eucheuma cottoniidi Kabupaten Luwu dan Kota Palopo

\section{Ketersediaan Ruang Perairan (Biocapacity)}

Ketersediaan ruang perairan (Biocapacity/BC) untuk budidaya rumput laut Eucheuma cottonii di Kabupaten Luwu dan Kota Palopo akan menggambarkan 2 komponen utama, yaitu 1) berapa luas keseluruhan suatu perairan tersebut yang mampu untuk mendukung budidaya rumput laut, serta, 2) seberapa besar produk rumput laut yang bisa dicapai (dengan asumsi pemakaian keseluruhan terhadap ketersediaan lahan yang ada).

Analisis Biocapacity didasarkan pada kesesuaian perairan yang mendukung budidaya rumput laut.Untuk mengetahui kesesuaian ruang perairan yang dapat dimanfaatkan budidaya rumput laut secara spasial menggunakan konsep evaluasi kesesuaian lahan.Konsep ini berdasarkan pada parameter fisika, kimia dan biologi perairan yang secara ekologis merupakan prasyarat kelayakan dalam budidaya rumput laut.Untuk itu digunakan teknik Sistem Informasi Geografis (SIG) untuk mengetahui luas perairan yang sesuai untuk budidaya rumput laut di Kabupaten Luwu dan Kota Palopo. Secara spasial, perairan Kabupaten Luwu dan Kota Palopo untuk pengembangan rumput laut Eucheuma cottonii dikelompokkan dalam 3 kategori yaitu kelas sangat sesuai (S1), sesuai (S2) dan tidak sesuai (N).

Perhitungan Biocapacity pada penelitian ini membagi menjadi Biocapacity parsial (berdasarkan masing-masing kategori kelas S1 dan S2) serta Biocapacity total (total luas lahan perairan dari kategori kelas S1 dan S2). Nilai Biocapacity di Kabupaten Luwu dan Kota Palopo juga dihitung untuk setiap musim yang berbeda, yaitu Biocapacity pada musim peralihan 1 (bulan Mei 2015) dan Biocapacity musim pelaihan 2 (bulan September 2015).

\section{Biocapacity Musim Peralihan 1}

Berdasarkan analisis Biocapacity parsial di perairan Kabupaten Luwu pada musim peralihan 1 dengan kategori sangat sesuai (S1) sebesar 569.061,80 ton dan kategori sesuai (S2) sebesar $575.685,06$ ton. Biocapacity total mencapai $1.144 .746,86$ ton yang artinya bahwa apabila dengan asumsi pemanfaatan seluruh lahan yang tersedia seluas 47.597,71 hektar, maka perairan tersebut mampu untuk menghasilkan produksi rumput laut sebanyak 1.144.746,86 ton/tahun.

Biocapacity parsial di perairan Kota Palopo pada musim peralihan 1 dengan kategori sangat sesuai (S1) 15.232,48 ton, sedangkan pada kategori perairan yang sesuai (S2) mampu memproduksi rumput laut sebanyak 41.017,09 ton.Biocapacity total di Kota Palopo sebesar $56.249,56$ ton yang artinya bahwa apabila dengan asumsi pemanfaatan seluruh lahan yang 
tersedia seluas 5.448,60 hektar, maka perairan tersebut mampu untuk menghasilkan produksi rumput laut sebanyak 56.249,56 ton/tahun.

\section{BiocapacityMusim Peralihan 2}

Berdasarkan analisis Biocapacity parsial di perairan Kabupaten Luwu pada musim peralihan 2 dengan kategori sangat sesuai (S1) sebesar 387.802,62 ton dan kategori sesuai (S2) sebesar $867.751,21$ ton. Biocapacity total mencapai $1.255 .553,83$ ton yang artinya bahwa apabila dengan asumsi pemanfaatan seluruh lahan yang tersedia seluas 52.204,98 hektar, maka perairan tersebut mampu untuk menghasilkan produksi rumput laut sebanyak 1.255.553,83 ton/tahun.

Biocapacity parsial di perairan Kota Palopo pada musim peralihan 2 dengan kategori sangat sesuai (S1) 0 ton, disebabkan kesesuaian lahan perairan dengan kategori sangat sesuai tidak ada (0 hektar), sedangkan pada kategori perairan yang sesuai (S2) mampu memproduksi rumput laut sebanyak 1,66 ton. Biocapacity total di Kota Palopo sebesar 1,66 ton yang artinya bahwa apabila dengan asumsi pemanfaatan seluruh lahan yang tersedia seluas 0,1608 hektar, maka perairan tersebut mampu untuk menghasilkan produksi rumput laut sebanyak 1,66 ton/tahun.

\section{Biocapacity Gabungan 2 Musim}

Berdasarkan analisis Biocapacity gabungan 2 musim yang merupakan gabungan dari musim peralihan 1 dan peralihan 2 di perairan Kabupaten Luwu, maka didapatkan hasil bahwa perairan dengan kategori sangat sesuai (S1) sebesar 327.539,62 ton dan kategori sesuai (S2) sebesar 1.110.239,98 ton. Apabila dengan asumsi kategori S1 dan S2 digabungkan maka Biocapacity total mencapai 1.437.779,60 ton yang artinya bahwa apabila dengan asumsi pemanfaatan seluruh lahan yang tersedia seluas 59.781,79 hektar, maka perairan tersebut mampu untuk menghasilkan produksi rumput laut sebanyak 1.437.779,60 ton/tahun.

Biocapacity gabungan 2 musimdi perairan Kota Palopo didapatkan hasil bahwa perairan dengan kategori sangat sesuai (S1) 0 ton, sedangkan pada kategori sesuai (S2) adalah 18.287,46 ton. Apabila dengan asumsi kategori S1 dan S2 digabungkan maka Biocapacity total di Kota Palopo mencapai sebesar 18.287,46 ton yang artinya bahwa apabila dengan asumsi pemanfaatan seluruh lahan yang tersedia seluas 1.771,41 hektar, maka perairan tersebut mampu untuk menghasilkan produksi rumput laut sebanyak 18.287,46 ton/tahun. Hasil analisis Biocapacity ditampilkan pada Tabel 2 dan Gambar 3.

Tabel 2. Biocapacityperairan di Kabupaten Luwu dan Kota Palopo.

\begin{tabular}{|c|c|c|c|c|c|c|c|c|}
\hline \multirow{3}{*}{ Musim } & \multicolumn{4}{|c|}{ Kabupaten Luwu } & \multicolumn{4}{|c|}{ Kota Palopo } \\
\hline & \multirow{2}{*}{$\begin{array}{l}\text { Produksi } \\
\text { (Ton)1 }\end{array}$} & \multicolumn{2}{|c|}{ BC Parsial (Ton) } & \multirow{2}{*}{$\begin{array}{l}\mathrm{BC} \\
\text { (Ton) }\end{array}$} & \multirow{2}{*}{$\begin{array}{l}\text { Produksi } \\
\text { (Ton) } 1\end{array}$} & \multicolumn{2}{|c|}{ BC Parsial (Ton) } & \multirow{2}{*}{$\begin{array}{l}\text { BC Total } \\
\text { (Ton) }\end{array}$} \\
\hline & & S1 & S2 & & & S1 & S2 & \\
\hline Peralihan & & $569.061,80$ & $575.685,06$ & $1.144 .746,86$ & & $15.232,48$ & $41.017,09$ & $56.249,56$ \\
\hline $\begin{array}{l}1 \\
\text { Peralihan } \\
2\end{array}$ & $235.823,93$ & $387.802,62$ & $867.751,21$ & $1.255 .553,83$ & $4.589,99$ & 0 & 1,66 & 1,66 \\
\hline $\begin{array}{l}\text { Total } \\
2 \text { musim }\end{array}$ & & $32.539,62$ & $1.110 .239,98$ & $1.437 .779,60$ & & 0 & $18.287,46$ & $18.287,46$ \\
\hline
\end{tabular}

\section{Daya Dukung Perairan}

Untuk mengetahui daya dukung suatu perairan berdasarkan analisis Ecological Footprint (EF), terdapat 3 komponen utama yang harus diketahui, yaitu : 1) berapa besar tingkat pemanfaatan perairan (dalam hal ini adalah Ecological Footprint Produksi/EF $\mathrm{E}_{\mathrm{P}}$ ), 2) berapa besar ketersediaan ruang perairan (Biocapacity/BC) yang mampu untuk mendukung kegiatan tersebut, serta, 3) berapa banyak jumlah sumberdaya manusia (kapita) yang memungkinkan untuk memanfaatkan ketersediaan ruang perairan yang ada. Dengan membandingan antara Biocapacity terhadap Ecological Footprint maka akan menghasilkan berapa besar daya dukung perairan. 

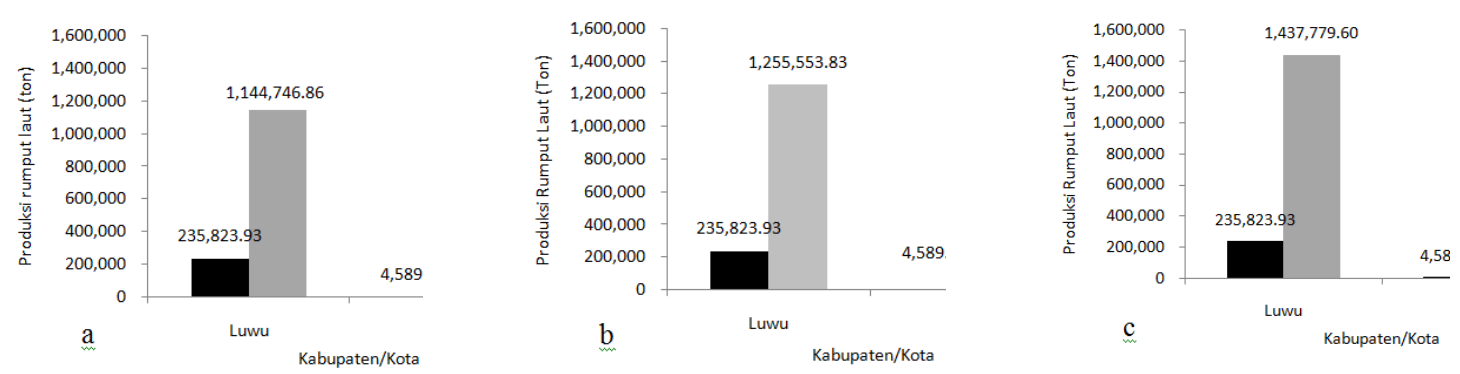

Gambar 3. Perbandingan ecological footprint produksi (EFp) dengan biocapacity $(\mathrm{BC})$ rumput laut Eucheuma cottonii, (a). musim peralihan 1, (b). musim peralihan 2, dan (c). total 2 musim

\section{Daya dukung musim peralihan 1}

Berdasarkan hasil analisis daya dukung dengan pendekatan EF di Kabupaten Luwu pada musim peralihan 1 menunjukkan bahwa tingkat pemanfaatan perairan $\left(\mathrm{EF}_{\mathrm{P}}\right)$ adalah 67,8883 ton/kapita (235.823,93 ton/tahun), sedangkan ketersediaan ruang perairan (Biocapacity/BC) adalah 47.597,71 hektar yang mampu untuk memproduksi rumput laut sebanyak 1.144.746,86 ton/tahun. Apabila menggunakan asumsi bahwa pemanfaatan seluruh ketersediaan lahan perairan yang ada (47.597,71 hektar), maka daya dukung jumlah sumberdaya manusia yang mungkin untuk dapat memanfaatkan lahan tersebut adalah 17.064 kapita.

Hasil analisis daya dukung perairan di Kota Palopo pada musim peralihan 1 menunjukkan bahwa tingkat pemanfaatan perairan $\left(\mathrm{EF}_{\mathrm{P}}\right)$ adalah 3.0876 ton/kapita $(4.589,99$ ton/tahun), sedangkan ketersediaan ruang perairan (Biocapacity/BC) adalah 5.448,60 hektar yang mampu untuk memproduksi rumput laut sebanyak 56.249,56 ton/tahun. Apabila menggunakan asumsi bahwa pemanfaatan seluruh ketersediaan lahan perairan yang ada (5.448,60 hektar), maka daya dukung jumlah sumberdaya manusia yang mungkin untuk dapat memanfaatkan lahan tersebut adalah 1.954 kapita.

\section{Daya dukung musim peralihan 2}

Berdasarkan hasil analisis daya dukung dengan pendekatan EF di Kabupaten Luwu pada musim peralihan 2 menunjukkan bahwa tingkat pemanfaatan perairan $\left(\mathrm{EF}_{\mathrm{P}}\right)$ adalah 67,8883 ton/kapita (235.823,93 ton/tahun), sedangkan ketersediaan ruang perairan (Biocapacity/BC) adalah 52.204,98 hektar yang mampu untuk memproduksi rumput laut sebanyak 1.255.553,83 ton/tahun. Apabila menggunakan asumsi bahwa pemanfaatan seluruh ketersediaan lahan perairan yang ada (52.204,98 hektar), maka daya dukung jumlah sumberdaya manusia yang mungkin untuk dapat memanfaatkan lahan tersebut adalah 18.716 kapita.

Daya dukung perairan di Kota Palopo pada musim peralihan 2 menunjukkan bahwa tingkat pemanfaatan perairan $\left(\mathrm{EF}_{\mathrm{P}}\right)$ adalah 3.0876 ton/kapita (4.589,99 ton/tahun), sedangkan ketersediaan ruang perairan (Biocapacity/BC) adalah 0,1608 hektar yang mampu untuk memproduksi rumput laut sebanyak 1,66 ton/tahun. Apabila menggunakan asumsi bahwa pemanfaatan seluruh ketersediaan lahan perairan yang ada (0,1608 hektar), maka daya dukung jumlah sumberdaya manusia yang mungkin untuk dapat memanfaatkan lahan tersebut adalah 0,60 kapita, atau setara dengan 1 kapita.

\section{Daya dukung total 2 musim}

Berdasarkan hasil analisis daya dukung perairan total 2 musim di Kabupaten Luwu menunjukkan bahwa tingkat pemanfaatan perairan $\left(\mathrm{EF}_{\mathrm{P}}\right)$ adalah 67.8883 ton/kapita $(235.823,93$ 
ton/tahun), sedangkan ketersediaan ruang perairan (Biocapacity/BC) adalah 59.781,79 hektar yang mampu untuk memproduksi rumput laut sebanyak 1.437.779,60 ton/tahun. Apabila menggunakan asumsi bahwa pemanfaatan seluruh ketersediaan lahan perairan yang ada (59.781,79 hektar), maka daya dukung jumlah sumberdaya manusia yang mungkin untuk dapat memanfaatkan lahan tersebut adalah 21.432 kapita.

Daya dukung perairan total 2 musim di Kota Palopo menunjukkan bahwatingkat pemanfaatan perairan $\left(\mathrm{EF}_{\mathrm{P}}\right)$ adalah 3.0876 ton/kapita (4.589,99 ton/tahun), sedangkan ketersediaan ruang perairan (Biocapacity/BC) adalah 1.771,41 hektar yang mampu untuk memproduksi rumput laut sebanyak 18.287,46 ton/tahun. Apabila menggunakan asumsi bahwa pemanfaatan seluruh ketersediaan lahan perairan yang ada (1.771,41 hektar), maka daya dukung jumlah sumberdaya manusia yang mungkin untuk dapat memanfaatkan lahan tersebut adalah 635 kapita. Hasil analisis daya dukung perairan disajikan pada Tabel 3.

Tabel 3. Daya dukung perairan berdasarkan analisis ecological footprint untuk rumput laut Eecheuma cottoniidi Kabupaten Luwu dan Kota Palopo.

\begin{tabular}{lllllll}
\hline \multirow{2}{*}{ Musim } & \multicolumn{5}{l}{ Kabupaten Luwu } & Kota Palpo \\
\cline { 2 - 7 } & $\begin{array}{l}\text { EFP } \\
\text { (Ton/Kapita) }\end{array}$ & BC (Ton) & $\begin{array}{l}\text { Daya Dukung } \\
\text { (Kapita) }\end{array}$ & $\begin{array}{l}\text { EFP } \\
\text { (Ton/Kapita) }\end{array}$ & BC (Ton) & $\begin{array}{l}\text { Daya } \\
\text { (Kapita) }\end{array}$ \\
\hline Peralihan 1 & & $1.144 .746,86$ & 17.064 & & $56.249,56$ & 1.954 \\
Peralihan 2 & 67,8883 & $1.255 .553,83$ & 18.716 & 3,0876 & 1,66 & $0,60 \approx 1$ \\
Total 2 musim & & $1.437 .779,60$ & 21.432 & & $18.287,46$ & 635 \\
\hline
\end{tabular}

Sumber : Hasil analisis, 2015

\section{Status Ekologi}

Status ekologi mencerminkan apakah tingkat pemanfaatan perairan melebihi dari kemampuan suatu perairan untuk mendukung kegiatan tersebut dan atau sebaliknya. Apabila tingkat pemanfaatan ruang perairan melebihi kemampuan ketersediaan lahan, maka status ekologi mengalami overshoot. Apabila tingkat pemanfaatan perairan lebih kecil daripada kemampuan ketersediaan lahan, maka status ekologi tersebut surplus.Status ekologi dinyatakan sebagai perbedaan antara biocapacity dan ecological footprint. Menurut Wackernagel dan Rees (1996) menyatakan bahwa status overshoot apabila $\mathrm{BC}<\mathrm{EF}$, sedangkan surplus ekologi apabila $\mathrm{BC}>$ EF. Dengan mengetahui status ekologi tersebut akan dapat memberikan pendugaan suatu wilayah apakah dalam pengelolaan sumberdaya tersebut berkelanjutan atau tidak. Berdasarkan hasil analisis tingkat pemanfaatan ruang perairan (EFP) serta ketersediaan kemampuan ruang perairan (BC) gabungan dua musim, maka status ekologi di Kabupaten Luwu mengalami surplus ekologi (BC > EFP, atau 922.928,96 ton/tahun > 235.823,93 ton/tahun), begitu juga dengan status ekologi di Kota Palopo mengalami surplus ekologi (BC > EFP, atau 10.115,34 ton/tahun $>4.589,99$ ton/tahun). Dengan demikian dapat dikatakan bahwa pengelolaan sumberdaya pesisir untuk budidaya rumput laut di Kabupaten Luwu dan Kota Palopo masih merupakan pengelolaan yang berkelanjutan.

\section{KESIMPULAN}

Berdasarkan analisis daya dukung perairan gabungan dua musim, maka dapat dijadikan acuan untuk pengembagan budidaya rumput laut di kedua wilayah studi. Hal tersebut diperkuat dengan hasil sebagai berikut: (a) Ketersediaan ruang (Biocapacity) dan daya dukung perairan untuk budidaya rumput laut di Kabupaten Luwu lebih besar dibandingkan dengan Kota Palopo, (b) Status ekologi pada dua musim untuk kedua lokasi studi masih kategori berkelanjutan. Dengan mempertimbangkan potensi tersebut, maka kontinyuitas usaha budidaya rumput laut dengan dua musim diharapkan menghasilkan produksi yang lebih optimal.

Salah satu faktor keberhasilan dalam budidaya rumput laut Eucheuma cottonii dengan metode long line adalah dengan mempertimbangkan musim yang ada. Musim barat (DesemberFebruari) adalah musim dengan karakteristik dengan gelombang dan arus laut yang cukup kuat, 
sehingga dapat mengakibatkan kerusakan tali ris pada rumput laut. Dengan mempertimbangkan kekuatan gelombang dan arus tersebut, dapat mengakibatkan daya dukung perairan akan menurun. Musim timur (Juni-Agustus) dengan karakteristik intensitas radiasi matahari yang tinggi sehingga suhu air laut juga akan mengalami peningkatan, maka hal tersebut juga harus menjadi pertimbangan dalam usaha budidaya rumput laut. Dengan mempertimbangan kedua musim tersebut, maka diperlukan informasi yang tepat dan ilmiah dalam menentukan lokasi yang benarbenar aman dan sesuai untuk dijadikan lokasi budidaya. Berdasarkan hasil analisis peta kesesuaian untuk budidaya rumput laut Euchemua cottonii maka disarankan untuk memilih lokasi berdasarkan analisis kesesuaian gabungan dua musim, sehingga lokasi tersebut kemungkinan tidak mengalami perubahan yang signifikan akibat perubahan musim.

\section{PERSANTUNAN}

Penelitian ini dibiayai oleh Pusat Penelitian dan Pengembangan Sumberdaya Laut dan Pesisir (P3SDLP), Badan Penelitian dan Pengembangan Kelautan dan Perikanan 2015. Penulis menyampaikan ucapan terima kasih kepada Tim survey Kabupaten Luwu dan Kota Palopo; Dr. Yonvitner dan Dr. Etty Riani atas diskusi dan masukannya dalam memperkaya substansi pada tulisan ini.

\section{DAFTAR PUSTAKA}

Aslan LM. 1998. Budidaya Rumput Laut. Yokyakarta: Kanisius.11-19Hlm.

Bala, B.K. and Md.A.Hossain. 2009. Integrated management of coastal zone for food security. Final Report.Bangladesh.Department of Farm Power and Machinery, Bangladesh Agricultural University. 19p.

Boyd CE dan Lichtkoppler F, 1982. Water quality management in pond fish culture.(4 $4^{\text {th }}$ Edition ed.).InternationalCenter for Aquaculture, Agriculture Experiment Station, Auburn, USA.

[DKP] Provinsi Sulawesi Selatan.2016. Laporan Temu Teknis Budidaya Rumput Laut, Makassar 2016.

[DKP] Dinas Kelautan dan Perikanan Kabupaten Luwu. 2015. Laporan tahunan perikanan Kabupaten Luwu Tahun 2010 2014. Belopa.DKP Kab.Luwu. 31Hlm.

[DKP] Dinas Kelautan dan Perikanan Kota Palopo. 2015. Laporan tahunan DKP Kota Palopo Tahun 2010-2014. Palopo.DKP Kota Palopo. 42Hlm.

Ewing, B., A. Reed, A. Galli, J. Kitzes, and M. Wackernagel. 2010. Calculation Methodology for the National Footprint Accounts. 2010 Edition. Oakland: Global Footprint Network. 3p.

Harrison, P.J. and C.L. Hurd. 2001. Nutrient physiology of seaweeds: Application of concepts to aquaculture. J. Cahiers de Biologie Marine, 42:71-82.

Hurd, C.L., P.J. Harrison, K. Bischof, and C.S. Lobban. 2014. Seaweed ecology and physiology. $2^{\text {nded. }}$ Cambridge.Cambridge University Press.238 p, 349 p.

KenFURUYA. 2004. EnvironmentalCarrying Capacity Inan Aquaculture Groundof Seaweed sand ShellfishinSanriku Coast. Bull.Fish.Res.Agen.SupplementNo.1,65-69,2004.

[KLH] Kementerian Lingkungan Hidup. 1988. Keputusan Menteri Negara Kependudukan dan Lingkungan Hidup Nomor 02 Tahun 1988 tentang Pedoman Penetapan Baku Mutu Lingkungan. Jakarta.

[KLH] Kementerian Lingkungan Hidup R.I. 2004. Keputusan Menteri Negara Kependudukan dan Lingkungan Hidup Nomor 51 Tahun 2004 tentang Baku Mutu Air Laut. Jakarta.

Rees WE. 1996. Revisiting carrying capacity: area-based indicators of sustainability. J Population and Environment, (17):195-215.

Schroll.H, J. Andersen and B. Kjærgård. 2012. Carrying Capacity: An Approach to Local Spatial Planning in Indonesia. The Journal of Transdisciplinary Environmental Studies vol. 11, no. 1, 2012.

Toda.S., O. Matsuda and M.Yamasaki. 2004. Ecosystem and Carrying Capacity of Aquaculture Ground -for sustainable development of aquaculture and stock enhancement. Seikai National Fisheries Research Institute, NAGASAKI 2-3 November 2004. Bull. Fish. Res. Agen. No. 19, 1-7, 2007.

Widigdo, B., J. Pariwono. 2003. Daya dukung perairandi pantaiutaraJawaBaratuntuk budidayaudang(Studi kasusdi KabupatenSubang,TelukJakarta dan Serang). Jurnal Ilmu-Ilmu Perairan dan Perikanan Indonesia, 1:10-17.

Yonvitner, S.B. Susilo, G. Rakasiwi, dan A.A. Taurusman. 2007. Daya dukung pulau-pulau kecil dengan pendekatan ekological footprint : Kasus di Pulau Wetar. Bogor.PKSPL IPB.12Hlm. 
Y. N. Tian and H. Q. Wang. 2013. Progress of Resources and Environmental Carrying Capacity. Journal of Clean Energy Technologies, Vol. 1, No. 2, April 2013.

Zhu, C. and S. Dong. 2013. Aquaculture Site Selection and Carrying Capacity Management in the People's Republic of China. InL.G. Ross, T.C. Telfer, L. Falconer, D. Soto \& J. Aguilar-Manjarrez, eds. Site selection and carrying capacities for inland and coastal aquaculture, pp. 219-230.FAO/Institute of Aquaculture, University of Stirling, Expert Workshop, 6-8 December 2010. Stirling, the United Kingdom of Great Britain and Northern Ireland. FAO Fisheries and Aquaculture Proceedings No. 21. Rome, FAO. 282 pp. 